\title{
NEW MEDIA'S POSITIVE AND NEGATIVE IMPACTS ON YOUTH
}

\author{
Selvira Draganović
}

International University of Sarajevo

\begin{abstract}
Contemporary living is marked by powerful presence and all present use of new technologies. We might boldly state that people might not function well without new media. We heedlessly witness large part of contemporary adolescent's social and emotional development occurring while on the Internet and on cell phones. Many parents and caregivers today use technology incredibly well and feel comfortable and capable with the programs and online venues that their children and adolescents are using. Nevertheless, some parents and adults are concerned about adolescent's overuse of new media due to their potential risks and negative impact on adolescent's psycho-social development. Some parents and caregivers may find it difficult to relate to their digitally savvy youngsters online for valid reasons. Such people may lack some basic understanding of adolescents and the new forms of socialization which is happening online, which are integral to their children's lives. Adolescent's limited capacity for self-regulation and susceptibility to peer pressure make youth particularly vulnerable and at risk for various risks as they navigate and experiment with social media. Primary aim of this paper is to shed some light on adolescent's online behavior and choices given their physical, cognitive, emotional, social, and behavioral characteristics and discuss potential negative and positive impact of new media on youth, family and social participation.
\end{abstract}

Keywords: Adolescence, adolescents, new media, risks, benefits. 


\section{Introduction}

Distinct from the traditional media such as TV and different printed materials, new media include and refer to all products/devices and services that provide information or entertainment using computers or the internet, among which very popular ones are: Smartphone, you tube, blogs, social networks like facebook, twitter, instagram etc. Contemporary living word is marked by presence of various technology devices and new media which seem to bring many advantages but disadvantages as well. Many worry about impact of new media on youth warning about their negative sides. The new Pew Research Center survey (2018) on social media use reveals YouTube, Instagram, Snapchat, Facebook and Twitter to be the most popular online platforms among US adolescents ages 13 to 17.

While the numbers on Smartphone ownership in advanced countries is higher than in emerging countries, it is estimated that five billion people have mobile devices and half of these are smartphones (GSM Association, 2018) with and 95\% of US adolescents owning a Smartphone. The study conducted by Lenhart and associates in 2011 (as stated by Reid \& Weigle, 2014 ) reports $76 \%$ of all teens use social media, $64 \%$ do so on a daily basis, and $41 \%$ have accounts on multiple sites. Hence, one can conclude that majority of adolescents all over the world own smart phones and that most of them log on to their social media site more often than not and we can assume that large part of this generation's social and emotional development is occurring while on the internet and on cell phones or smart phones. No wonder many are concerned about impact of new media on youth.

However, in order to better understand why adolescents are using new media this much, which seems close to almost being addictive, we should foremost consider main psychological characteristics of adolescence, thus characterizing/ categorizing new media impact on youth, family and their impact on youth's social participation either positive or negative. Given the transitional stage of adolescence and whilst keeping in mind that adolescents are considered to be adults in waiting, in order to understand adolescents' healthy and unhealthy behaviors, we begin with tackling their physical, cognitive, emotional, social, and behavioral development.

\section{Psychological characteristics of adolescents}

Adolescence is primarily marked by transition from childhood into adulthood which is characterized by important physical, cognitive, psychosocial and emotional development. Diverse physical changes such as physical growth, sexual development, hormonal changes which are resulting in gross changes in appearance and body image, occur during adolescence and make the common characteristics of adolescent's physical development. At this stage of life adolescents become very and seriously concerned about their body image and reputation among their peers. Hence, what their peers do, what they approve or disapprove, how they behave, is very important to adolescents. Adolescents might be prone to early and/or risky sexual behavior, substance use eating disorders and even depression. Because of this concern and they might use new media not only to check their peers but also to share their concerns with them or to look for solutions for their concerns (Andrews \& Hopes, 2010; Carr, 2016; Brent, Poling \& Goldstein, 2011; Agras, 2010).

Adolescence is the time when abstract thinking finally develops, something that children were not able to do till this stage of life. This ability, next to poor understanding of how both, positive and negative emotions affect their thinking and behavior, however might result in adolescents' poor decision making skills. This might lead to adolescent's poor ability to limit time spent on internet, media usage, prioritize, focusing and accomplishing school tasks. Considering adolescents serious concern about themselves and their position among peers it is important to understand that adolescents may fear potential negative social consequences of their choices more than they do possible health risks (i.e., being rejected and ostracized for not sharing all on facebook profile or instagram versus possible risks posed doing so or on line predators). At this stage of life adolescents exercise their reasoning skills which reflect in their self centered attitudes (Jaffe, 1998), frequent acting over dramatic, arguing for the sake of arguing and constantly find faults in adults' position (Bjorklund, 2011).

At adolescence, moral development becomes important part in youth's life too. Adolescents voice and share their values and ethical behavior, which serve as foundation of pro-social behavior such as altruism, helping, moral and ethics (Shaffer \& Kipp, 2014). Pro-social behavior is modeled after adults 
and peers. Thus, new media might serves as powerful tool for modeling pro and/or anti-social behavior. This is the time when adolescents, if encouraged and positively reinforced in society might start volunteering and this way, positively contributing and participating in society. It should be emphasized that adolescents are hungry for meaning and they might benefit extremely from positive role models and explicit discussions of moral values as well as community in which there are activities structured around pro-social values, including religious values (Shaffer \& Kipp, 2014) .

In terms of emotional development of adolescents, this is the time of establishing coherent sense of identity and learning to cope with stress and managing emotions. The sense of identity includes two concepts of the self, the self concept (who am I, roles, goals, values), and self esteem (evaluating how one feels about self concept). The self concept and its development is under the influence of both, cognitive and physical development ad uniquely develops for each adolescent (Bjorklund 2011). Thus, adolescents who manage to develop healthy body and good body image will be more able to deal with their concerns will have foundation to develop healthy self concept (Shaffer \& Kipp, 2014).

Adolescence time is marked by adolescents' experimenting with different ways of appearing, sounding, and behaving. Social media and content shared on social media might contribute, positively or negative to, adolescents development of the self. Instead of letting adolescents learn through media adults can help adolescents to understand how emotions can affect their thinking and behavior and help them learn good and healthy coping skills by fostering their self competence. Otherwise, their peers and media might will fill in this gap and serve as a resource, which might be not only untrue but also dangerous. In order to help adolescents smoothly transit into adulthood and become critical and selective of media content, adults can engage in honest, open conversation with them by asking them, in non-threatening way and listening nonjudgmentally, trying to match their emotional state, model rational decision making strategies, discuss ethical and moral problems in news and in social media.

Social development of adolescents in this phase of their life relates to peers, family, school, work, and community. Adolescence is the time when huge shift from family to peer group happens. During adolescence peer groups serve a number of important functions among which, providing a temporary reference point for a developing sense of identity, is of extreme importance because through identification with peers, adolescents begin to develop moral judgment and values (Shaffer \&Kipp, 2014) and to define how they differ from their parents (Gullotta et al., 2015). At the same time, however, it is important to note that adolescents also strive, often covertly, for ways to identify with their parents. Another important function of peer groups is to provide adolescents with a source of information about the world outside of the family and about themselves (Gullotta et al., 2015). Hence we can state that peer groups also serve as powerful reinforces during adolescence, as sources of popularity, status, prestige, and acceptance. Positive peer relations are linked to positive psychosocial adjustment and negative behaviors might be linked to social isolation.

Adolescence is the time when dating and sexual behavior of teens also become important to them. Internet and new media are full of online sites providing advice on attraction, dating cites, cyber dating etc. which sensibly pose many threats to potential user, sexting, internet harassment, sexual victimization (Delmonico \& Carnes, 1999; Schneider 2012; Reid \& Weigle, 2014). Given that adolescents cell phone usage is on increase and that adolescents communicate great deal via social media they might also be more likely to use this technology to communicate and share their distress and suicidal thoughts with others, what can be both, risk and protective factor (Ruder et al., 2011). Media, new media especially, can be used as paltform and forum for expressing suicidal ideation as some studies report (Ruder et al., 2011) on severeal cases of individuals who, prior to commiting suicidal act, have shared their intent and plan via social media.

Although adolescence is also considered to be the time of palpable parent -teen conflict resulting in parental distress as parent might be thinking of it as rejection but in essence it is not because parentteen conflict is normal in adolescence, through conflict adolescents are showing their parents they are steaming of and becoming individuals (Tahirović, Draganović, Sofović, 2018).

Finally, it is important to state that all of the ways adolescents develop, cognitively, physically, 
emotionally and socially, prepare them to experiment with new behaviors as they transit from childhood to adulthood. Risk taking in adolescence is an important way that adolescents shape their identities and develop their self, try out their new decisionmaking skills, and develop realistic assessments of themselves, other people, and the world (Shaffer \& Kipp, 2014). Such exploratory behaviors are natural in adolescence (Santrock, 2016), and teens need to be given some room to experiment and to experience the results of their own decision making in many different situations (Dryfoos, 2012). However, young people sometimes overestimate their capacities to handle new situations, and these behaviors can pose real threats to their physical health. There are three theories which explain this adolescent's behavior:

1. One theory stresses the need for excitement, fun, and novel, intense sensations that override the potential dangers involved in a particular activity (Arnett \& Balle-Jensen, 1993).

2. Another theory stresses that many of these risk behaviors occur in a group context and involve peer acceptance and status in the group (Jessor, 1991).

3. And third theory emphasizes that adolescent risk taking is a form of modeling and romanticizing adult behavior (Gibbons \& Gerrard, 1995). By and large, we may say that adolescents experience numerous psychological changes which mark this stage of their life representing distinctive marks of adolescence.

\section{Adolescence and adolescents}

In view of adolescence as transitional stage from childhood to adulthood and considering adolescents themselves adults in waiting, so to say, neither children anymore nor adults yet, this puts them in, somehow ungrateful position. This developmental phase of life can be a time of both, disorientation and discovery. Adolescence brings up very important issues of self independence and self identity and myny adolescents and their peers face tough choices regarding schoolwork, risky behaviors such as sexuality, drugs, alcohol, and social life whilst peer groups, romantic interests, and external appearance tend to naturally increase in importance for some time during an adolescents' journey toward adulthood ( Shaffer \& Kipp, 2014).
Moreover, adolescence is marked by adolescents' frequent and rapid mood switching which waver between happiness, anguish, self-confidence and anxiety (Carr, 2016). However, we must keep in mind that some of these shifts in moods originate not only from biological resources but also complex social interactions including conflicts with friends, pressure from school and experimentation with relationships (Santrock, 2012). During adolescence, teenagers try to manage their emotions and uncertainties, to discover where they fit in with peers and their place in society. More often, adolescents experience an unsteady sense of self and experiment with new personal labels and relate to a number of peer groups (Shaffer \& Kipp, 2014).

At adolescence, peer relationships are given priority over family relationships. Adolescents often seek opinions from and perceptions of their friends; they are readily influenced by their peers' behaviors and beliefs. During this stage, teenagers are extremely vulnerable to negative peer pressure. Adolescents are also characterized by their search for independence. While doing so, teenagers most often test the boundaries placed by their teachers and parents. In addition, adolescents develop a selfcentered attitude and look at situations from their own perspectives.

All in all, we can say that adolescence is marked by emotions, personal identity, peer relationships, self centered attitudes, independence and testing boundaries. New media play very important role in adolescent's psycho-social development. Many show concern in terms of possible negative impact and influence of new media on youth and family (Delmonico \& Carnes, 1999; Schneider 2012; Reid \& Weigle, 2014).

Nevertheless, we have to emphasize that media are innately neither positive nor negative. Human nature is discovered through the use of internet and not vice versa (Giles, 2010). Given this all, we may talk about media impact which, because of their users can go in two directions, unhealthy/negative influence or risks or challenges of new media and healthy/positive/ beneficial impact of new media. We discuss these two separately in coming parts. 


\section{Negative influence/risks or challenges of new media and their impact on youth}

Among most common and concerning risks and challenges of new media we name the management of personal information and privacy. This risk might lead to the following, the risk of predation and cyberbullying and online harassment, sexting, Face Book depression (Livingstone \& Brake 2009; Livingstone 2008; Livingstone and Helsper 2007; Schneider 2012; Reid \& Weigle, 2014; Carr 2016). Scientists warn that those who suffer from Facebook depression are at risk for social isolation and sometimes turn to risky Internet sites and blogs for "help" that may promote substance abuse, risky and/or unsafe sexual practices, or aggressive or selfdestructive behaviors, violence, terrorism; (Ruder et al. 2011; Schneider 2012; Reid \& Weigle, 2014). According to Child exploitation and Online Protection Centre (CEOP, 2006), due to digital footprint, another new media risk, safety and wellbeing of young people using Social Network Sites are of particular concern to parents.

Scientists warn that young people lack awareness of the public nature of the internet (Acquisti and Gross 2006). Additionally, new media or better to say, inability to limit time spent on internet and daily usage of new media, might present detriment to work and/or school (cheating, grades, admission, productivity and success, employment prospects, time wasting).

On the top of the threat of abuse, some fear that young people's use of Social Network Sites can compromise the development and maintenance of supportive friendships and involvement in institutions traditionally understood as the embodiment of "communities", namely school, sports clubs, families, partners etc. (Delmonico \& Carnes 1999).

Despite all these aforementioned risks, there is some evidence that young people are aware of potential privacy threats online and many proactively take steps to minimize potential risks (Lenhart \& Madden 2007; Hinduja \& Patchin 2009). Furthermore, research has indicated that online risks „, are not radically different in nature or scope than the risks minors have long faced offline, and minors who are most at risk in the offline world continue to be most at risk online" (Palfrey et al. 2008 p. 7).

\section{Healthy/positive influence of new media on youth}

Given the negative impact of new media on youth, family and community participation one may wonder about existence of new media's benefits or positive impact. Yet, there are numerous benefits or impact of new media on youth, among which psychological ones are crucial considering adolescents' developmental stage.

Whilst fearing negative impact of media and new media in particular parents and caregivers naturally question the benefits of new media. Studies in this area do suggest that new media may be beneficial in fostering of one's individual identity and unique social skills like socialization and communication, enhanced learning opportunities, accessing health information, (Ito et. al., 2008). And also, new media may play a positive role in enhancement of individual and collective creativity through development and sharing of artistic and musical endeavors (Boyd and Ellison, 2007), instilling growth of ideas from the creation of blogs, podcasts, videos, and gaming sites (Ito et al, 2008). New media might also be beneficial in expansion of one's online connections through shared interests to include others from more diverse backgrounds (Ellison et al, 2007). Social media might be offering opportunities for community engagement through raising money for charity and volunteering for local events, including political and philanthropic events (Ito et. al, 2008, Boyd, 2007).

Nonetheless it is important to note that it is not media themselves solely which play a positive or negative role in adolescents and family psychosocial development and their community participation, there are other significant factors. Next to the media and all that they bring with, adolescents, namely their psychological characteristics, skills, capacities, competencies, also play an important role in positive or negative impact of new media on youth. Then, family, family relations and parents-children relations, family values, family time and of course, wider social factors and resources in societies, opportunities, values etc. 


\section{Conclusion}

Even though we notice negative/unhealthy impact of new media and youth, family and social participation, new media can, at the same time have positive/healthy impact on youth. With joint forces we should, all, work on enhancing positive or healthy media usage and strengthen their positive impact on youth because they can help improve adolescent's behavior through: media literacy, education, creativity, individual identity and self expression, strengthening interpersonal relationships, sense of belonging and collective identity, strengthening and building communities, civic engagement and political participation, wellbeing.

All in all, media literacy and usage can improve quality of adolescents' lives. Thus, this should not be taken lightly and discarded due to their possible negative impacts. 


\section{References}

» Acquisti, A., \& Gross, E. F. (2006). Imagined Communities Awareness, Information Sharing, and Privacy on the Facebook. Paper presented at the Privacy Enhancing Technologies Workshop, Cambridge, UK.

» Agras, W. (2010). The Oxford handbook of eating disorders. Oxford University Press, New York.

»Andrews, J., \& Hops, H. (2010). The influence of peers on substance use. In L. Scheier (Ed.), Handbook of drug use aetiology: Theory, methods, and empirical findings (pp. 403-420). American Psychological Association, Washington, DC.

» Arnett, J., \& Balle-Jensen, L. (1993). Cultural bases of risk behavior. Child Development, 64, 1842-1855.

» Bjorklund, D. (2011). Children's thinking: Cognitive development and individual differences (5th ed.).Cengage, Belmont, CA.

» Boyd, d., \& Ellison, N. (2007). Social Network Sites: Definition, History, and Scholarship. Journal of ComputerMediated Communication, 13(1).

» Brent, D., Poling, K., \& Goldstein, T. (2011). Treating depressed and suicidal adolescents: A clinician's guide, Guilford Press, New York.

»Carr A., (2016). The handbook of child and adolescent clinical psychology a contextual approach, Routledge, Taylor and Francis Group, London and New York.

» Child exploitation and Online Protection (CEOP, 2006). Understanding Online Social Network Services and Risks to Youth: Stakeholder perspectives. Child Exploitation and Online Protection Centre, London.

» Delmonico, D.L. \& Carnes, P.J. (1999) „Virtual sex addiction: when cybersex becomes the drug of choice" in Cyberpsychology \& behavior: the impact of the Internet, multimedia \& virtual reality on behavior and society 2(5):457- 463.

»Dryfoos, J. G. (2012). Safe passage: Making it through adolescence in a risky society. Oxford University Press, New York.

» Ellison, N., Steinfield, C., \& Lampe, C. (2007). The Benefits of Facebook "Friends:" Social Capital and College Students' Use of Online Social Network Sites. Journal of Computer-Mediated Communication, 12(4). Gibbons, F. X., \& Gerrard, M. (1995). Predicting young adults' health risk behavior. Journal of Personality and Social Psychology, 69, 505-517.

» Giles D., (2010). Psihologija medija. Clio.Beograd.

» Gullotta, T. P., Plant, R. W., Evans, M (Eds.) (2015). Handbook of Adolescent Behavioral Problems: EvidenceBased Approaches to Prevention and Treatment, Springer, US.

» Henggeler, S., Cunningham, P., Rowland, M., \& Schoenwald, S. (2012). Contingency management for adolescent substance abuse: A practitioner's guide, Guilford Press,New York.

"Hinduja, S., \& Patchin, J. (2009) Bullying Beyond the Schoolyard: Preventing and Responding Cyberbullying. Thousand Oaks, Sage Publications, Corwin Press, CA.

» Ito, M., Horst, H. A., Bittanti, M., Boyd, d., Herr-Stephenson, B., Lange, P. G., et al. (2008). Living and Learning with New Media: Summary of Findings from the Digital Youth Project. The John D. and Catherine T. MacArthur Foundation, Chicago.

» Jaffe, M. L. (1998). Adolescence. Wiley, New York.

» Jessor, R. (1991). Risk behavior in adolescence: A psychosocial framework for understanding and action. Journal of Adolescent Health, 12, 597-605.

» Lenhart, A., \& Madden, M. (2007). Teens, Privacy \& Online Social Networks: How teens manage their online identities and personal information in the age of MySpace. Washington, DC: Pew Internet \& American Life Project. Cyberbullying Thousand Oaks, CA: Corwin Press.

» Livingstone, S. (2008a). Taking Risky Opportunities in Youthful Content Creation: Teenagers' Use of Social Networking Sites for Intimacy, Privacy and Self Expression, New Media \& Society, 10 (3), 393-411.

» Livingstone, S., \& Helsper, E. J. (2007). Taking risks when communication on the Internet: the role of offline social-psychological factors in young people's vulnerability to online risks. Information, Communication \& Society, 10(5), 619-643.

» Livingstone, S., and Brake, D. (2009) On the rapid rise of social networking sites: New findings and policy implications. Children and Society, 24(1): 75-83. 
Micucci, J. A. (1998). The adolescent in family therapy: Breaking the cycle of conflict and control. Guilford, New York.

» Palfrey J, Gasser U, Boyd D (2010). Response to FCC Notice of Inquiry 09-4: "Empowering Parents and Protecting Children in an Evolving Media Landscape." Berkman Center for Internet and Society at Harvard University Cambridge, MA.

» Palfrey, J., Sacco, D. Boyd, d.. DeBonis, L. (2008). Enhancing Child Safety \& Online Technologies: Final Report of the Internet Safety Technical Task Force, Harvard University, Berkman. Ponton, L. E. (1997). The romance of risk: Why teenagers do the things they do. Basic Books. New York.

» Reid D., \& Weigle P., (2014). Social Media Use among Adolescents: Benefits and Risks. Adolescent Psychiatry, 2014, 4, 73-80.

» Ruder, T. D., Hatch, G. M., Ampanozi, G., Thali, M. J., \& Fischer, N. (2011). Suicide announcement on Facebook. Crisis. 32, 280-282.

» Ruder, T. D., Hatch, G. M., Ampanozi, G., Thali, M. J., \& Fischer, N. (2011). Suicide announcement on Facebook. Crisis. 32, 280-282.

» Santrock, J. W. (2016). Adolescence (16th.ed.), McGraw-Hill, New York.

» Schneider, S. K. O'Donnell, L., Stueve, A., \& Coulter, R. W. (2012). Cyber-bullying, school bullying, and psychological distress: A regional census of high school students. American Journal of Public Health. 102, 171-177.

» Shaffer, D. and Kipp, K. (2014). Developmental Psychology: Childhood and Adolescence. 9th ed, Wadsworth Cengage Learning, Belmont.

» Tahirović S, Draganović S., Sofović J, (2018). Napredno roditeljstvo: Priručnik za prevenciju nailnog ekstremizma. El-Kalem, Sarajevo.

» The Mobile Economy 2018 Copyright (C) 2018 GSM Association, retrieved from https://www.gsma.com/ mobileeconomy/wp-content/uploads/2018/05/The-Mobile-Economy-2018.pdf, January 2020. 